University of Puget Sound

Sound Ideas

All Faculty Scholarship

Faculty Scholarship

$7-2017$

\title{
Finding oneself while discovering others: An existential perspective on volunteer tourism in Thailand
}

Nick Kontogeorgopoulos

IPE, konto@pugetsound.edu

Follow this and additional works at: http://soundideas.pugetsound.edu/faculty_pubs

Part of the Tourism Commons

\section{Citation}

Kontogeorgopoulos, N. (2017). Finding oneself while discovering others: An existential perspective on volunteer tourism in Thailand. Annals of Tourism Research, 65, 1-12.

This Article is brought to you for free and open access by the Faculty Scholarship at Sound Ideas. It has been accepted for inclusion in All Faculty Scholarship by an authorized administrator of Sound Ideas. For more information, please contact soundideas@pugetsound.edu. 


\title{
Finding oneself while discovering others: An existential perspective on volunteer tourism in Thailand
}

\author{
Nick Kontogeorgopoulos \\ University of Puget Sound, 1500 North Warner, Tacoma, WA 98416, USA
}

\section{A R T I C L E I N F O}

\section{Article history:}

Received 5 August 2016

Revised 2 February 2017

Accepted 11 April 2017

\author{
Keywords: \\ Existential authenticity \\ Inter-personal \\ Intra-personal \\ Volunteer tourism \\ Thailand
}

\begin{abstract}
A B S T R A C T
The purpose of this study is to explore the importance of existential authenticity in the motivations and activities of volunteer tourists in Thailand. Although studies of volunteer tourism have hinted at the importance of existential themes, few have explicitly utilized an existential framework to assess the authenticity of volunteer tourist experiences. The findings of this study illustrate that the volunteer tourism experience is driven by a desire for existential authenticity in both its intrapersonal and interpersonal varieties, and that working with children facilitates existentially authentic outcomes for volunteers. At the same time, while the perceived material authenticity of hosts enhances opportunities for existential authenticity, it simultaneously undermines it because cultural differences hinder prospects for deep levels of bonding and understanding.
\end{abstract}

(C) 2017 Elsevier Ltd. All rights reserved.

\section{Introduction}

For the past several decades, tourists from high-income countries have increasingly turned to alternative forms of travel that, in theory, deliver rewarding experiences and promise beneficial economic, environmental, and social outcomes for destination communities (Isaac, 2010; McGehee, 2002; Pearce, 1992). The fastest growing example of this shift towards alternative travel experiences is volunteer tourism, which "makes use of holiday-makers who volunteer to fund and work on social or conservation projects around the world and aims to provide sustainable alternative travel that can assist in community development, scientific research or ecological restoration" (Wearing, 2004, p. 217). The growth of volunteer tourism in recent years has been dramatic, both in terms of the number of individual participants, and the number of volunteer programs being offered around the world (Callanan \& Thomas, 2005; Tomazos \& Butler, 2009; TRAM, 2008). As volunteer tourism opportunities have proliferated globally, particularly in low- and middle-income countries, there has also been a corresponding expansion of scholarly interest in the motivations, consequences, and activities associated with volunteer tourism (Benson, 2011; Lyons \& Wearing, 2008; McGehee \& Santos, 2005; Wearing, 2001).

There are many reasons for the rising popularity of volunteer tourism. On the one hand, volunteer tourists are said to be motivated by altruism, as expressed by the desire to help people in need, give back, or make a difference in the lives of others (Brown, 2005; Coghlan, 2015; Stoddart \& Rogerson, 2004; Wearing, 2003). On the other hand, many of the motivations ascribed to volunteer tourists stem from 'social egoism,' a primitive form of egoism based on the promotion of values such as "our own survival, advancement over others, and gratification (amongst others)" (Coghlan \& Fennell, 2009, p. 381). Egoistic, as opposed to altruistic, motivations that inform volunteer tourism include self-development (McIntosh \& Zahra, 2007), fun (Halpenny \& Caissie, 2003), overcoming a challenge (Galley \& Clifton, 2004), career development (Söderman \& Snead,

E-mail address: konto@pugetsound.edu 
2008), bonding with family members (Bruyere \& Rappe, 2007), the acquisition of cultural capital (Jones, 2011), novelty (Pearce \& Coghlan, 2008), and adventure (Stoddart \& Rogerson, 2004).

The pursuit of authenticity is another important egoistic force behind the growth of volunteer tourism. The role played by authenticity in the motivations, actions, and beliefs of tourists has long captured the interest of scholars (Belhassen, Caton, \& Stewart, 2008; Cohen, 1988; MacCannell, 1976; Olsen, 2002; Hughes, 1995). The longstanding study of authenticity in the tourism literature has produced a wide variety of theoretical approaches, leading some to believe that the "the term and concept should be abandoned in any research that discusses the genuineness of objects and activities, because the different concepts, values, and perspectives on the authenticity of objects and activities are numerous, contradictory, and irreconcilable" (Reisinger \& Steiner, 2006, p. 66).

It is possible, however, despite the heterogeneous use of the term, to clearly identify two overarching approaches to authenticity in the context of tourism. First, object-related authenticity relates to the genuineness, accuracy, or truthfulness of material objects that can include "life processes (e.g., cooking and washing), activities (e.g., recreational games, religious rituals, cultural performances), artifacts, and so on” (Lau, 2010, p. 480). Although most popular and academic notions of object authenticity focus either on activities such as festivals, rituals, or performances, or objects such as food, art, or clothing, Pearce and Moscardo (1986) indicate that tourists also care about the perceived characteristics of people and settings, which in turn provide the focal points of a tourist gaze searching for symbols of authenticity.

The second approach to authenticity in the tourism literature is rooted in the work of existential philosophers such as Heidegger, Camus, Kierkegaard, Nietzsche, and Sartre. Although significant differences exist among these philosophers, authenticity from an existentialist perspective relates to a person's response to the realization that life has no intrinsic meaning or purpose, that we must expect to feel alienation and anxiety as a result of this realization, and that we bear ultimate and sole responsibility for the individual choices that we make, as well as for the particular meanings that we create for ourselves, independent of any grand narratives. Living authentically from an existential point of view means embracing and accurately representing, rather than running away from, one's true self. It also means constantly reflecting on one's past and future, striving to understand one's true identity, and being true to oneself as often as possible, even when doing so challenges norms and expectations established by others. When individuals live in a way that fails to reflect their true selves, they take the path of least resistance and conveniently surrender to what Heidegger calls inauthenticity, or what Sartre calls 'bad faith.'

In a seminal article that prompted a shift in the way that many tourism scholars discuss authenticity, Wang (1999) distinguishes between object-related authenticity and activity-related authenticity, the latter of which is an existential form of authenticity that "involves personal or intersubjective feelings activated by the liminal process of tourist activities" (Wang, 1999, p. 351). Known by several other names, including 'hot authenticity' (Cohen \& Cohen, 2012; Selwyn, 1996), 'relationship authenticity' (Lau, 2010), and the 'tourist moment' (Cary, 2004), existential authenticity is produced by those tourist experiences that "offer an opportunity to re-evaluate and discover more about the self, to act out one's self-image as a way of modifying or correcting it" (Brown, 2005, p. 481).

According to Wang (1999), tourism can facilitate two kinds of existential authenticity: intra-personal authenticity, which consists of bodily feelings and 'self-making,' and inter-personal authenticity, which relates to experiences that enhance family bonds or contribute to touristic communitas. This paper employs the framework established by Wang (1999) in order to examine the role played by intra-personal and inter-personal existential authenticity in the motivations and activities of volunteer tourists in northern Thailand. Further, even though previous studies of volunteer tourism in Thailand have touched upon relevant existential themes such as intimacy (Conran, 2011), camaraderie (Broad \& Jenkins, 2008), personal challenge (Coren \& Gray, 2012), self development (Broad, 2003), and family bonding (Proyrungroj, 2014), the discussion of existential authenticity itself is only an incidental component of these studies, and as a result remains underexplored in the existing literature. This paper attempts to address these gaps, and argues that a desire for intra-personal and inter-personal existential authenticity heavily shapes the motivations of volunteer tourists, as well as the perceived benefits of the volunteer experience.

\section{The relationship between volunteer tourism and existential authenticity}

When the theme of authenticity is addressed in the volunteer tourism literature, it is usually approached from an objectrelated perspective that focuses on the authenticity of material objects, people, or settings (Alexander \& Bakir, 2011; Chen \& Chen, 2011; Pan, 2012). However, a small number of scholars in recent years have begun to identify existential authenticity as a primary lens through which to assess volunteer tourism. For example, Mittelberg and Palgi (2011) explore the ways in which international kibbutz volunteers in Israel attain intra-personal existential authenticity by undergoing a high degree of self-development. They argue that interactions among volunteers, and between volunteers and hosts, also promotes interpersonal existential authenticity because volunteers feel a lasting bond with their fellow volunteers and with local communities.

Another example of the overt use of an existential authenticity framework comes from McDonald and Wilson (2013). After summarizing the ways in which Heidegger and Sartre conceived of authenticity from an existential perspective, McDonald and Wilson explore how the anxiety that volunteer tourists often feel creates opportunities to experience existential authenticity. Further, although existentialists such as Heidegger believe that every individual Dasein ('being-in-the-w 
orld') is free and solely responsible for choosing how to respond to the meaninglessness and absurdity of life, this does not mean that we exist alone without others. In other words, since "existence arrives already imbued with others" (McDonald \& Wilson, 2013, p. 111), inter-personal existential authenticity is always theoretically possible when tourists and hosts interact, but only when these interactions are respectful, reciprocal, and sincere. McDonald and Wilson contrast volunteer tourism with backpacking and mass tourism, and argue that the former fosters a sense of inter-personal existential authenticity because it features intimacy and "affords a degree of mutual exchange and interaction that is uncommon in other forms of tourism" (p. 111).

Studies that explicitly link volunteer tourism to existential authenticity are rare, but existential authenticity does relate indirectly to the findings of many studies, even when they fail to utilize the concept explicitly. As mentioned earlier, Wang (1999) distinguishes between intra-personal and inter-personal existential authenticity, with the former consisting of bodily feelings and self-identity. Bodily feelings, which can include "relaxation, rehabilitation, diversion, recreation, entertainment, refreshment, sensation-seeking, sensual pleasures, excitement, play, and so on" (Wang, 1999, p. 361), are mentioned by several authors as volunteer tourist motivations (Callanan \& Thomas, 2005; Daldeniz \& Hampton, 2011; Wymer, Self, \& Findley, 2010).

By contrast, the exploration and enhancement of self-identity are well-established themes in the volunteer tourism literature. Wang (1999) indicates that since many individuals find it hard to pursue self-realization due to the constraints of everyday roles, tourism offers opportunities for self-making and the development of one's self-identity. This seems also to be true with volunteer tourism, and generic concepts such as personal development, self-development, and personal growth are often used when discussing the benefits of volunteer tourism (Tiessen, 2012; Uriely, Reichel, \& Ron, 2003; Wearing, 2001).

As an example of intra-personal existential authenticity, self-making consists of four specific themes that run throughout much of the existing research on volunteer tourism. First, volunteer tourism is believed to lead individuals to greater awareness, knowledge, and understanding of the self (Lepp, 2008; Pan, 2012; Wickens, 2011). In one of the earliest studies of volunteer tourism, Wearing (2001) characterizes volunteer tourism as a series of experiences that make a difference, but the difference made is presumably not just for local communities. In particular, he states that the "most important development that may occur in the volunteer tourist experience is that of a personal nature, that of a greater awareness of self" (Wearing, 2001, p. 2).

Second, like all forms of tourism, volunteer tourism presents opportunities for introspection and reflection on one's life because it takes tourists out of quotidian settings and familiar relationships (Bailey \& Russell, 2012; McIntosh \& Zahra, 2007). Unlike conventional tourism though, volunteer tourism features activities and interactions with hosts that do not revolve primarily around service, recreation, and entertainment. Hence, by its very nature, volunteer tourism lends itself to explorations of philosophical, existential questions such as: "How can I go on living my life as I used to? What are my values? And how should I choose to live my life?" (Zahra, 2011, p. 99).

Third, Wang (1999, p. 363) demonstrates that the challenges associated with being away from familiar, everyday environments can lead to self-making in that a new self is discovered or molded when one survives 'trials of the self.' A desire to be challenged is a volunteer tourist motivation mentioned in several studies (Galley \& Clifton, 2004; Grimm \& Needham, 2012). As Zahra and McIntosh (2007) argue, since many young international volunteer tourists are sheltered from material hardship at home, coming face-to-face with the suffering of others while abroad poses a great challenge and causes anxiety and discomfort. However, overcoming this challenge, not to mention the challenge of "working in a foreign culture and climate, dealing with their emotions and working with others" (Broad, 2003, p. 68), allows volunteers to "see what they are made of (Schott, 2011) while also leading to greater self-confidence (Proyrungroj, 2014).

Fourth, the intra-personal theme most commonly linked to volunteer tourism is personal transformation (Coghlan \& Weiler, 2015; Diprose, 2012; Lee \& Woosnam, 2010; Sherraden, Lough, \& McBride, 2008). McGehee and Santos (2005) argue that the distinctiveness of volunteer tourism helps to explain why it provides opportunities for consciousness-raising, while Coghlan and Gooch (2011, p. 716) treat volunteer tourism as a form of transformative learning, which "changes problematic sets of reference to frames of reference that are more inclusive, discriminating, open, reflective and emotionally able to change." Much of the discussion of volunteer tourism's ability to foster personal transformation emphasizes the substantial and long-lasting impacts of the experience on the lives of volunteers (Bailey \& Russell, 2010).

Coverage of existential themes in volunteer tourism centers largely on intra-personal existential authenticity, but Wang's (1999) two kinds of inter-personal existential authenticity, namely 'family ties' and 'touristic communitas,' also inform the findings of several volunteer tourism case studies. For those who volunteer abroad with their children, the experience provides opportunities to impart life lessons and teach children the importance of values such as giving (Brown, 2005; Lo \& Lee, 2010). By removing family members from their everyday routines and constraints, and placing them in situations that are potentially transformative, volunteer tourism also encourages family cohesion and bonding (Bruyere \& Rappe, 2007; Mustonen, 2007).

Feelings of inter-personal togetherness also exist between volunteers themselves (Kim \& Jamal, 2007). Many authors comment on the importance of camaraderie between volunteers, who appreciate meeting like-minded individuals that share their values, interests, and commitment to travelling in a manner that is perceived to be responsible and meaningful (Brown, 2005; Mustonen, 2007). Lastly, advocates of volunteer tourism portray it as a means of achieving inter-personal existential authenticity between volunteers and hosts (Barbieri, Santos, \& Katsube, 2012; McIntosh \& Zahra, 2007). Of particular relevance to the forging of deep inter-personal connections is the perceived sincerity of the interactions that take place between volunteers and locals in backstage settings far removed from the scripted and commercialized spaces of conventional tour- 
ism. Additionally, as an "embodied experience that arouses a sense of closeness and a story about a shared experience" (Conran, 2011, p. 1459), the intimacy of volunteer-host interactions is a key motivation, benefit, and facilitator of interpersonal existential authenticity.

\section{Methods}

This study is based on research conducted with volunteer tourists and volunteer tourism organizations in the province of Chiang Mai, located in northern Thailand. Despite its tremendous growth as a tourism destination in recent years, Thailand has nevertheless retained its reputation among foreign tourists as an exotic location that has yet to become overly predictable, overvisited, or 'modern.' Further, although Thailand officially became an upper-middle income country in 2011 according to the World Bank's classification of the world's economies, some Westerners still consider it a part of the socalled 'Third World,' with all the connotations of poverty, deprivation, and dependency that this entails. Thailand's emergence as a volunteer tourism location is therefore related to a desire to visit a popular tourism destination while also doing so in away that helps one stand apart from the increasing numbers of conventional tourists visiting the country. Of course, volunteer tourism also represents, for some visitors to Thailand, a way to make a greater contribution to local communities while also, as this paper argues, pursuing and experiencing authenticity in both its object-related and existential varieties.

Among the many specific locations in which volunteer tourism takes place in Thailand, Chiang Mai is the most popular, accounting for one-third of all volunteers in Thailand (Keese, 2011, p. 265). The way that volunteer tourism is organized in Chiang Mai creates opportunities for a wide range of volunteers, including those interested in environmental conservation, English-language instruction in Buddhist temples and public schools, and community service with non-governmental organizations (NGOs) that deliver services to marginalized populations such as disabled children, orphans, refugees, and victims of domestic abuse. NGOs are crucial to the volunteer tourism industry in Thailand. In Chiang Mai, volunteer tourism is facilitated and coordinated by eight ground operators. While only some of these eight ground operators are non-profit entities, they all work closely with NGOs, as well as government institutions such as schools. There are also, of course, institutions and NGOs that recruit their own international volunteers, but the majority of volunteers working in Chiang Mai either come directly through a ground operator, or arrange their trips indirectly through one of nearly 20 global booking agencies that channel volunteers to the eight local ground operators in Chiang Mai.

This paper is based on research conducted over a total of 8 months, spread out during four separate visits between 2012 and 2016. Since the "search for existentially authentic experiences results in a preoccupation with feelings, emotions, sensations, relationships, and self" (Rickly-Boyd, 2012, p. 273), it was decided that qualitative methods best fit the purpose of this research, particularly as they enable a fruitful examination of subjective phenomena such as those mentioned above.

Several methods were employed in this research. First, semi-structured interviews were conducted with 71 volunteers and 16 directors, managers, and staff members of seven volunteer ground operators. Interview subjects were selected through purposive sampling, and interviews lasted between 45 minutes and three hours. Interviews were transcribed manually and, in order to protect the anonymity of respondents, all names were altered. Transcribed data were then coded and evaluated using Nvivo, a qualitative data analysis software program that helps to identify trends, themes, and patterns in large sets of unstructured data.

Second, informal conversations that were not recorded or structured in any systematized way elicited additional data that were captured as field notes. These informal conversations often yielded similar information as the data gathered in recorded interviews, but also produced insights or factual information that led to refinements in the questions being asked in the more formal recorded interviews. As with transcribed data, field notes were also evaluated using Nvivo.

Lastly, the author engaged in participant observation, with the focus on the latter, in the locations where volunteers undertook their activities; these locations include public elementary and high schools, Buddhist temples, and social welfare institutions. Unlike some other studies of volunteer tourism (Sin, 2009; Vrasti, 2012; Zavitz \& Butz, 2011), in which the researcher participates formally in a volunteer project as part of an 'auto-ethnographic' methodological approach (Barbieri et al., 2012), the author of the current study never paid to participate in a volunteer project, and also avoided assuming a formal role with any of volunteer tourism ground operators in Chiang Mai. The author's identity as a researcher was therefore always clear and unambiguous. While being an 'outsider' surely yielded different information than would have been gathered as an 'insider,' it proved beneficial because respondents were able to share their thoughts in an environment free of established group norms, expectations, or pressures to perform a particular identity to managers, local coordinators, or fellow volunteers.

\section{Finding oneself: volunteer tourism and intra-personal existential authenticity}

When asked to comment on their reasons for choosing to volunteer in Thailand, as opposed to travelling in a more conventional manner, volunteers express sentiments similar to those reported in other studies of volunteer tourism. Besides wanting to participate in community service projects that aim to improve the lives of locals, volunteers commonly mention a desire for novelty, adventure, and skill acquisition. There is also a noticeable concern among volunteers to travel in ways that enable them to stand apart from more conventional tourists in Thailand. Motivations for volunteering are numerous, and vary by each individual, but the one theme that unites the experiences of virtually all volunteer tourists interviewed 
for this research is authenticity, whether one approaches it from a material or existential perspective. While it is beyond the scope of this paper to examine in detail the importance of object-related authenticity to volunteer tourists, it should be noted that a desire to experience authentic Thai culture, and more importantly the authentic lives of 'real' Thais, factors significantly in both the motivations and perceived benefits of short-term volunteer experiences (Kontogeorgopoulos, 2016). At the same time, conversations and interactions with volunteers in Thailand reveal that motivations related to existential authenticity are just as, if not more, important to volunteers as having what is perceived to be a culturally authentic experience.

\section{Bodily feelings: The physical and emotional benefits of volunteer tourism}

As discussed earlier, Wang (1999) points out that tourism is able to provide two kinds of intra-personal existential authenticity: bodily feelings and self-making. Both kinds of intra-personal authenticity characterize the narratives of volunteers in Thailand. At a general level, volunteer tourism in Thailand involves some of the same activities and outcomes as any other type of vacation, in that volunteers usually travel throughout the country or region before or after the official duration of their volunteer experience. Further, volunteers often assume the role of the tourist on their days off, and therefore engage in touristic activities that contribute to such bodily feelings as relaxation, sensual pleasures, and sensation-seeking. Because most volunteers spend periodic moments as ordinary tourists, it could be argued that volunteer tourism offers the same bodily benefits as tourism generally. In the Thai context, this includes the restorative effects of warm weather, as illustrated by Kerri from Sweden:

To be honest, I'm not that fond of Asia. I'm more of a European person, I think. But I love the climate and the weather. For me, that's what I like about it. Sun. I need sun. And daylight. We don't have any daylight in Sweden. I like the fact that it's always sunny. It makes me feel happy to wake up and see the sun, so the weather, definitely, is a big plus for me.

It may be possible to satisfy bodily needs by travelling to Thailand as a volunteer, but since the actual volunteer experience itself-independent of side or incidental travel-involves activities that are often physically demanding and related more to work than leisure, it could also be argued that volunteer tourism does not generally match conventional tourism's ability to gratify "sensual pleasures, feelings, and other bodily impulses" (Wang, 1999, p. 362). On the other hand, bodily desires are not just physical in nature, but psychological and emotional as well. From this perspective, several scholars have noted that volunteer tourism satisfies several lower-level needs identified by Maslow (1954) in his classic "hierarchy of needs' model (Brown, 2005; Mustonen, 2007; Pan, 2012). Of particular note is love, a basic human need that informs the discourse and practice of volunteer tourism (Conran, 2011). Maslow (1954, p. 89) states that once physiological and safety needs are met, people will seek to satisfy "love and affection and belongingness needs," with the love needs specifically involving not just receiving love, but also giving love as well.

Love is a dominant theme in the reflections of volunteer tourists in Thailand, many of whom believe that the opportunity to make members of local communities feel valued and loved is one of the most rewarding aspects of their volunteer experience. Even more important, however, is the satisfaction that comes from receiving love and affection from hosts. In this regard, children are essential not only because they tend to demonstrate unrestrained affection compared to adults, but also because children more readily accept and respond to the love and affection of volunteers (Tomazos \& Butler, 2012). Echoing the views of many other volunteers, JoEllen from England commented on the uninhibited affection shown to her by local children:

The kids are very affectionate and then it's the hugs; they come and run and hug you and sit all over you and they're playing with your hair and there's not really any holding back. I expected them to be a little standoffish, but they're very loving. To me, it's very enjoyable because the kids show you in so many ways that you make them happy, and that makes me very happy.

Although critics of volunteer tourism are correct to argue that "by focusing on the child in international volunteer tourism, questions of politics and power are swept under the rug of innocence" (Mostafanezhad, 2013a, p. 492), it is undeniable that children also serve another purpose, namely to serve as loving and affectionate agents of intra-personal existential authenticity. It is probably for this reason that, despite a need among Thai adults for social services, volunteer tourism projects in Thailand and elsewhere work almost exclusively with children in schools, orphanages, and other social welfare institutions.

\section{Self-making in the liminal spaces of volunteer tourism}

In addition to fulfilling certain emotional needs, the volunteer tourism experience enables exploration and realization of the self because, like tourism generally, it represents a liminal activity in which the familiar constraints, norms, obligations, roles, and expectations associated with everyday life are altered, suspended, or reversed (Graburn, 2001; Turner, 1969). Aside from encouraging individuals to invert normal routines and patterns of behavior, tourism can also create a space for reflection where individuals are able to ponder their past and future. As Brown (2013) points out, Heidegger uses the term Spielraum to describe this liminal space and time, where individuals can take a break from the quotidian, and thereby explore a "range of possibilities for pursuing a particular course of activity or a particular identity" (Wrathall, 2013, p. 189). Spielraum, which Inwood (1999, p. 166) translates as "room to move, leeway, elbow-room, free play," is relevant when exam- 
ining the existential dimensions of volunteer tourism because the volunteering experience places people in unfamiliar liminal settings, and this is crucial since the "routines associated with everydayness have a tranquillising effect that dull the senses and free people from the burden of facing difficult existential questions" (Brown, 2013, p. 180).

Taken as a whole, the volunteer experience in northern Thailand encourages individual reflection in the Spielraum and thereby facilitates the exploration and enhancement of self-identity. For many volunteers, working in unfamiliar settings on projects that are believed to be meaningful encourages reflection about one's priorities and values, while also enabling contemplation of life choices and direction. Several respondents stated that they chose to spend time in Thailand as community service volunteers because they wanted time away from the distractions of home in order to ponder the direction of their lives. This was not only true for gap year students or recent college graduates, but also for middle-aged volunteers hoping to make a transition from one career to another. For example, when asked why she chose to volunteer in Thailand for two months, Stella from the United States stated the following:

I want to travel, I want to take time for me, I want to find my way, I want to find my way of life, for a long time this time.

Not just for a project, but my own project of life. I said 'ok, go away for a while. See how you feel when you are away from home. See how you do with this work.' Now I just have to take time for me for reflection and see what I want to do.

The reason that volunteer tourism encourages self-exploration and self-making is that liminal settings and interactions feature the absence, or at least reduction, of everyday pressures to perform certain roles or to meet the expectations of "significant others (referring to people with influence on an individual's self-evaluation)" (Schott, 2011, p. 57). Writing about tourism in general, Kim and Jamal (2007, p. 184) state that "within a liminal touristic space, conventional social norms and regulations are often temporarily suspended as tourists take advantage of the relative anonymity and freedom from community scrutiny."

Being true to oneself, and being exactly whomever one wants to be, are both themes hit upon by volunteers in their comments on the benefits of their experiences. In particular, the perception that one can exist authentically stems largely from anonymity and a freedom from social expectations, as illustrated by Jordyn, a Canadian volunteer in her sixties:

There's no question, there's an anonymity. I can be anybody, anything. I think there is a freedom to be. There are no expectations and there are also no accommodations you have to meet with your kids, with your grandchildren, with your friends, with all the things you have at home. You really leave it all behind. That is a kind of never-never-land. It's a great feeling and I believe that when I get home, I will be different. I do. I think I will be more..I don't want to use the word assertive, that's not what I mean. More able to express in a positive and kind way, what I want, who I am, and what I am willing to do.

Just as they serve an essential role in allowing the volunteer experience to fulfill the emotional needs of individual volunteers, children also foster the self-making dimension of intra-personal existential authenticity, principally because their openness and perceived innocence allow volunteers to simply be themselves without fear of judgment or embarrassment. Ellie, an American volunteer working at a home for disadvantaged children, captured this sentiment well:

You go there and you play and you have fun and there are no real expectations of the role that you need to fulfill. You are just there to give the kids attention and I think play is quite a natural thing. You go and, everyone loves to play, so it's not a huge deal. It's been real personal development because you can just be yourself. And I guess it opens you up to realize different things about yourself and you definitely become more aware.

Besides encouraging self-discovery, interacting with children reveals alternative ways of being in the world that allow volunteers to temporarily suspend the normal 'presentation of self' that takes place in everyday society (Goffman, 1959). This, in turn, allows volunteers to ponder the possibilities of being more true to themselves once they return home, as illustrated by Grace from Ireland:

It's a lot easier to not worry about how you look in this environment. It's so fun because you can be so silly. For me back home, public speaking is not something that I enjoy doing. But here, and maybe with younger kids especially, I just don't care at all. It's so much fun to be extremely cheesy and silly. You can do anything. You can dance or make funny faces or be really loud. I feel like, I wish I could be like that all the time. I feel like it's making me realize that whatever I do later, I want to be just like that.

Related to the statement above, many volunteers seem to come to an appreciation of both what they have, and what they lack, back home. On the one hand, working directly with marginalized populations and witnessing, or at least learning about, the difficult circumstances under which others live provides perspective for volunteers, and reminds them of reasons for which they should be grateful. On the other hand, volunteers appreciate what they believe is the relaxed, gracious, and introspective nature of Thai culture; this perception of Thai social and cultural values encourages volunteers to reflect on those things that 'really matter,' which to Liam from Australia includes the need "to slow down - really slow down and see the importance of life rather than striving to have that white picket fence, the big house, and the good car, and all that." On this note, Crossley (2012, p. 94) criticizes volunteer tourists for using the destitution of others "to trigger emotions such as sadness and guilt, which in turn facilitate the positive change in the self," while Mostafanezhad (2013b) decries the depiction of poverty in Thailand as authentic and cultural. These are certainly legitimate points, but considering that the consequences of volunteer tourism for locals is in most cases no more harmful than other forms of tourism in Thailand, the benefits of volunteering in fostering an appreciation of one's life is something that cannot be overlooked. 
Lastly, volunteers interviewed for this research often characterize their experiences as challenging but rewarding, in that they force volunteers to not only cope with a range of unfamiliar situations and people, but also to spend time reflecting on their values, personalities, past experiences, and future possibilities. These 'trials of the self,' as Wang (1999, p. 363) calls them, stem from the anxiety that is created by several features of the volunteer experience, including having to spend potentially long periods of time away from home, living with strangers in volunteer housing, and working in a social and cultural environment that can often feel completely alien to foreigners. Anxiety is a state of mind embraced by existentialists, since it "creates the conditions for insight and reflection on the conditions of existence" (McDonald \& Wilson, 2013, p. 114). The reflection prompted by this anxiety is itself a source of further anxiety and challenge, because volunteers are forced (at times reluctantly) to look deep within themselves, or as one male Dutch volunteer put it, to "meet yourself, and run into yourself."

As unnerving as it may be, coping with the anxiety of becoming a "law unto themselves in the absence of everyday norms and cultural sanctions" (McDonald \& Wilson, 2013, p. 114) presents a clear challenge for volunteers to overcome. For many volunteers in Thailand, overcoming various challenges is also ultimately a source of pride, achievement, and self-confidence. It is for this reason that volunteers often mention in interviews that they deliberately sought experiences outside their comfort zones in order to test, and learn about, themselves. For example, in response to a question about what she was hoping to get out of volunteering, Kelly from England stated:

I wanted to just challenge myself to be outside of my comfort zone and find out who I am when the pressure is on. It's very easy to stay who you are with all of your flaws when you have this comfort around you. You can only push yourself so far, so you need to put yourself in other situations so that you can be challenged in different ways because you never really know how to challenge yourself till you, I don't know, you have a different experience that's challenging you in a way you never thought you would be challenged.

The ability of volunteer tourism in Thailand to promote self-identity and self-development illustrates that the volunteer experience fulfills not just lower-level needs such as love, but also higher-order needs such as esteem and self-actualization, the highest item on Maslow's hierarchy of needs. According to Maslow (1954), people have a need for self-respect, selfesteem, a stable evaluation of themselves, and the esteem of others. Volunteer tourists in Thailand achieve both 'subsidiary sets' of esteem needs identified by Maslow. First, as illustrated above, volunteers clearly satisfy the need for achievement, adequacy, and "confidence in the face of the world" (Maslow, 1954, p. 90). Second, the human need for recognition, attention, and appreciation is also cultivated by the volunteering experience. In addition to receiving signs of appreciation from locals with whom them work, volunteers comment that they are also affirmed by friends and family back home who consider volunteering abroad an act of altruism. The achievement of self-actualization, which Maslow (1954, pp. 91-92) defines as "the desire to become more and more what one is, to become everything that one is capable of becoming," is indeed rare for any person, including volunteer tourists, but it is undeniable that for some volunteers at least, the experience furnishes brief moments of self-actualization.

\section{Discovering others: volunteer tourism and inter-personal existential authenticity}

Due to its focus on selfhood, and its premise that individuals are ultimately alone to create meaning in a meaningless and absurd world, existentialism may appear at first glance to promote a solipsistic and antisocial view of the world. However, key existentialist philosophers such as Heidegger and Sartre explore the embeddedness of individuals in society and the "inevitable sociability of existence" (Golomb, 1995, p. 98). For example, in Being and Time, Heidegger (1962, p. 344) points out that individuals are inextricably linked to one another:

Resoluteness, as authentic Being-one's-Self, does not detach Dasein from its world, nor does it isolate it so that it becomes a free-floating 'I' . . Resoluteness brings the Self right into its current Being-alongside what is ready-to-hand, and pushes it into solicitous Being with Others.

Recognizing that authentic bonds with others "makes possible the right kind of objectivity, which frees the Other in his freedom for himself" (Heidegger, 1962, p. 159), tourism scholars taking an existential approach to authenticity highlight the potential of tourism to foster authentic interactions and relationships between tourists. In the case of volunteer tourism specifically, McDonald and Wilson (2013) believe that barriers between tourists, locals, and the environment are dissolved because working and living alongside locals leads to intimate interactions and a high degree of mutual exchange.

According to Wang (1999), tourism can promote inter-personal existential authenticity by strengthening family ties and facilitating 'touristic communitas.' Although several studies indicate that family bonding is an important motivation for volunteer tourists (Lo \& Lee, 2010; Mustonen, 2007; Proyrungroj, 2014), it did not factor heavily in the experiences of the volunteers interviewed in Thailand for this research. This is likely a consequence of the timing of this research, which did not coincide with extended school holiday periods in volunteer-sending countries in Europe and North America.

\section{Bonding with other volunteers: Touristic communitas}

Although there is only a limited degree to which volunteers in Chiang Mai pursue inter-personal existential authenticity through strengthened family ties, the development of touristic communitas, by contrast, remains strong among volunteers. In his discussion of the ways in which tourism provides access to authentically experienced touristic communitas, Wang 
(1999) draws on the work of Victor Turner in order to demonstrate similarities between the motivations of pilgrims and modern tourists. According to Turner, the liminality associated with rituals and rites of passage produces communitas, a "modality of social relationship" (Turner, 1969, p. 96) associated with unstructured and temporary communities "in which individuals, stripped of socio-economic attributes are treated as equals, joined by common belief and purpose” (Rickly-Boyd, 2012, p. 98). Similarly, Wang (1999) argues that the liminal nature of many tourism experiences engenders moments of communitas between tourists searching for authentic inter-personal emotional connections. In this way, tourism, like communitas itself, represents the "abrogation, negation, or inversion of the normative structure in which its participants are quotidianly involved” (Turner, 1982, p. 47).

As a shared liminal and emotional experience, volunteer tourism in Thailand is conceived and practiced in ways that virtually guarantee communitas among participants. Just as it creates opportunities for intra-personal reflection and therefore self-exploration and discovery, liminality is also the crucial feature of volunteer tourism that yields opportunities for interpersonal authenticity. In particular, volunteers find it much easier to interact with strangers and make new friends when they are removed from their everyday norms, expectations, and responsibilities. Some volunteers commented that they find it hard to make new friends at home, but the absence of preexisting social networks in Thailand had forced them to interact and forge inter-personal connections with other volunteers. There is, in other words, no escape from yourself or from others in the intense, intimate social spaces occupied by volunteers:

When you're volunteering at home and you're going out and working as well, you go out and do your thing and you come back: you can be whoever you want to be at work and then come home. So, you know, you can be two different people, whereas, in this kind of environment, you don't have that opportunity. You're around each other 24 hours of the day, 7 days a week, so there's no hiding from who you are or who each other is. (Jenn, Canada)

In their study of the role played by existential authenticity in the experiences of Renaissance festival participants, Kim and Jamal (2007) indicate the pertinence of several properties associated with Turner's (1969) notion of communitas. Three of these properties-equality, acceptance, and the ludic nature of interactions-also apply to the findings of this study on volunteer tourists in Thailand. Despite featuring a diversity of nationalities, socio-economic backgrounds, and especially ages, volunteers commonly express a feeling of equality among participants. This sense of equality stems both from the sharing of a new and challenging experience, and the belief that volunteers are joined together in a common purpose, namely participation in local community service projects. Camaraderie and a certain esprit de corps therefore quickly emerge because volunteers are thrown together into the proverbial deep end, as explained by Jack, an American manager working for one of Chiang Mai's volunteer ground operators:

In general, it's a huge bonding experience for them [volunteers] because they're in this raw state, they're all going through so much and experiencing so much together, that it's like. . you know, the camp mentality. They develop these friendships and relationships in such a short time that carry on. And you know, you see them, they remain friends for a long period of time, a lot of them.

Since there is little escape from oneself or from others, acceptance is a logical outcome of the close interactions that occur between volunteers. Every middle-aged and elderly volunteer interviewed for this research expressed satisfaction with the degree to which they were accepted and included by other volunteers, the majority of which are much younger (usually between the ages of 18 and 25). Further, living and working closely with strangers from all over the world requires acceptance of personalities that would normally be avoided, either deliberately or inadvertently, at home. This opens up possibilities to nurture inter-personal connections that are unlikely outside the liminal settings of volunteer tourism:

The minute you get here, you make friendships left and right. Everyone's just in the same boat. Especially because you're usually all the way on the other side of the world, and you don't know the language, and you don't know much. You form connections pretty quick. Back home, if I met any of the people that I formed a close relationship with here, I could meet them and we might not ever talk. It's sort of like, why are you talking to me? They have their own little social circles. Here, because you're on the other side of the world and you're in the minority, you tend to get close. (Matt, United States).

Compared to equality and acceptance, the ludic nature of interactions between volunteers emerged as a pertinent expression of communitas more during the direct author observations than during interviews. Though there are rules and norms that govern what volunteers are expected to do on site, interactions between individual volunteers-particularly those who teach in pairs, or visit social welfare institutions in small groups-often feature spontaneous and unstructured playfulness. Opportunities to engage in playful behavior lead to inter-personal bonding and allow volunteers to "suspend the reality, anxiety, and pressures of everyday and work roles" (Kim \& Jamal, 2007, p. 194).

\section{Bonding with the cultural 'Other': The quest for sincere and meaningful interactions with hosts}

Though neglected in the literature on existential authenticity, the forging of authentic bonds with locals is just as important as the bonding that takes place between individual volunteers. In the case of Thailand, the daily interactions that take place between volunteers and locals clearly lead to meaningful inter-personal connections. Volunteer tourism lends itself very well to the creation of inter-personal existential authenticity because of the spaces in which volunteering takes place. The settings that host volunteers in Chiang Mai-namely schools, temples, medical clinics, and social welfare institutions- 
are judged by volunteers to be quotidian 'back regions' (MacCannell, 1973) that allow foreigners to catch glimpses of Thai social life inhabited by 'real' Thais who are unscripted and therefore seemingly sincere and authentic.

Shepherd (2015) wisely interrogates the common sentiment that it is impossible for certain categories of tourists (particularly mass tourists) to achieve existential authenticity. However, it is also true that in the absence, or at least reduction, of commercialization and staging in volunteer tourism spaces, individuals are better positioned to interact with one another in more meaningful ways, thereby potentially achieving a level of human interconnectedness and empathy that is considered by some observers to be rare in the predictable and circumscribed settings of conventional tourism (McDonald \& Wilson, 2013).

As discussed already, children play an important role in delivering perceived intra-personal benefits such as love, affirmation, and self-esteem, but they additionally offer volunteers a readily available means of achieving inter-personal bonding with locals. In light of the short amount of time spent by most volunteers in Thailand, the lack of knowledge about Thai cultural norms, the absence (in most cases) of a longstanding interest in Thailand, and most importantly the huge language barrier that exists between volunteers and the locals with whom they interact, children offer a quick and straightforward way of making a human connection to individuals belonging to a foreign culture. The irrelevance of the language barrier when dealing with children is illustrated by Kallen from the Netherlands:

With the kids, the language barrier isn't as big of a barrier as with adults. Like, with adults, when you don't share that common language, I feel it's much harder to get close to them. With the kids though, you don't need that as much, they just come and play with you, you can do sign language or whatever and draw pictures, and that'll be fine. The kids will try to speak Thai with us and even if we don't understand, we just nod our heads, but at the end of the day, they still love us and come hug us.

Volunteer interactions with children also feature a high degree of physical contact, manifested through hugs and other means of demonstrating affection. Physical contact between volunteers and children is important because it creates a sense of inter-personal intimacy, closeness, and bonding; these are outcomes that are otherwise hindered by the various norms and expectations that serve to limit such unconstrained signs of affection between volunteers and adult hosts.

Drawing on the ideas of symbolic interactionists such as Goffman (1959), one could also argue that the carefullycultivated 'presentation of self' that occurs among adults is absent among young children, whose spontaneity, sincerity, and lack of predictability obviate the need to negotiate and penetrate multiple layers before truly knowing another person. In other words, making a human connection with a 7-year-old Thai schoolchild is quicker, less complicated, and fraught with considerably less anxiety and awkwardness than making such a connection with, for instance, a middle-aged male Burmese refugee staying at a Thai social welfare institution. The ease of bonding with children is especially significant in a Thai social and cultural context in which one's innermost self is closely guarded because the "world outside the trusted home is presented as fearsome, threatening and unreliable" (Mulder, 2000, p. 58). Several volunteers lamented the difficulty of getting to know, and make friendships with, Thai adults beyond a superficial level. Dealing with children, by contrast, enables what are perceived to be sincere and meaningful interactions. Best of all, from the perspective of volunteers, since children accept volunteers unconditionally and without suspicion or confusion regarding their intentions or motivations, pathways for interpersonal bonding are made readily available when participating in community service activities centered on children.

\section{Conclusion}

This paper has highlighted the central role played by the search for existential authenticity in shaping the motivations of volunteer tourists, framing the discourse surrounding volunteer tourism, and guiding individual beliefs regarding the benefits associated with overseas volunteer activity. Though several authors have indicated that volunteer tourism in Thailand promotes, or is premised upon, such themes as camaraderie (Broad \& Jenkins, 2008), intimacy (Mostafanezhad, 2014), selfconfidence (Proyrungroj, 2014), and sentimentality (Mostafanezhad, 2013a), few have explicitly framed these themes in the context of existential authenticity. Further, the data on which this paper is based indicates that despite the importance of various other motivations-including the acquisition of career skills, the desire to help others, and the need for novelty and adventure-and regardless of such factors as age, duration of participation, level of previous travel experience, and nationality, the most significant and frequently-cited reasons given by volunteers for choosing to participate in community service while visiting Thailand all relate to various dimensions of existential authenticity.

Aside from confirming the importance of existential authenticity to the motivations and experiences of volunteer tourists in Thailand, this paper also hints at an important connection between different kinds of authenticity. In particular, contrary to those who argue that existential authenticity "can have nothing to do with the authenticity of toured objects" (Wang, 1999, p. 352), the example of volunteer tourism in northern Thailand corroborates the argument made by several authors (Gnoth \& Wang, 2015; Lepp, 2008; Steiner \& Reisinger, 2006; Wang, 2007) that object-related authenticity is often necessary, or at least conducive, to the pursuit of both intra-personal and inter-personal existential authenticity. Like most other tourists in Thailand (Kontogeorgopoulos, 2003), volunteers interviewed for this research consider material, or cultural, authenticity to derive from either stereotypical Orientalist conceptions of exotic Thai culture, or settings that are removed from commercial, staged mass tourism locations. In practice, what this means is that object-related authenticity is associated with unscripted and culturally pure Others inhabiting the back regions in which everyday local life takes place. 
Object-related authenticity is therefore closely associated with liminality and alterity, both of which are important features of the volunteer experience, as discussed throughout this paper. More specifically, features of intra-personal existential authenticity such as self-reflection and self-discovery, which depend on being outside of one's comfort zone in unfamiliar settings and situations, are best achieved under highly authentic (in material terms) circumstances in which the cultural, social, and economic differences between volunteers and locals are most conspicuous. Similarly, the inter-personal bonding between volunteers that leads to touristic communitas emerges most organically when volunteers find themselves in culturally unfamiliar (and thus materially authentic) environments that not only force volunteers to cope with common challenges, but also produce a unifying sense of mission and purpose, namely the desire to assist locals judged to be simultaneously disadvantaged and culturally authentic. Of course, as many volunteers admit in interviews, sincere and meaningful encounters with locals are also most memorable and emotionally satisfying when the hosts in question are deemed to be as exotic and authentic as possible: hence, rather than seeking to bond with commercially-motivated Thai tourism-industry employees, or middle-class Thais with similar socioeconomic backgrounds and experiences, volunteers instead seek out 'real' Thais who embody the cultural authenticity so valued by Western tourists.

While it is obvious that volunteer tourism in Thailand delivers a sense of existential authenticity to volunteers, it is worth noting several constraints and contradictions. First, as mentioned above, there is generally a positive relationship between feelings of existential authenticity and perceptions of the cultural authenticity of Thai hosts and settings. However, the very things that make object authenticity possible in the first place are the very same things that circumscribe opportunities for existential authenticity. For example, although the desire for (and the rewards associated with) inter-personal encounters with locals are greatest when cultural, social, and economic differences are most pronounced, these differences (most notably the language barrier) serve in practice to hinder prospects for deep levels of inter-personal bonding and understanding between volunteers and hosts.

Second, liminal situations and settings, which offer volunteers a reprieve from everyday life and thereby open spaces for intra-personal self-reflection and self-awareness, must necessarily be constrained and managed carefully by volunteer tourism organizations because too much liminality and suspension of everyday comforts such as order, routine, and safety can easily lead to alienation and frustration among volunteers. There is, in short, a constant tension among volunteers between a desire to escape the boredom and pressures of everyday life at home, on the one hand, and a desire for a certain minimal level of order and routine in their 'home away from home,' on the other.

Third, it should be acknowledged that one could reasonably question whether it is necessary to leave home in the first place to experience existential authenticity. If, as Steiner and Reisinger (2006, p. 303) argue, tourism research should embrace "the practices and values of philosophy so it does not oversimplify some of the most complex debates in philosophy," then the application of existentialism as a philosophy to volunteer tourism, as well as to other forms of travel, needs to be done carefully. On this note, although this paper applies the framework of existential authenticity established by Wang (1999) in order to illustrate the existential dimensions of volunteer tourism, Shepherd (2015, p. 66) points out that Heidegger, the philosopher cited most often by tourism scholars interested in existential authenticity, "never appears to have contemplated travel as a means of experiencing authenticity." Hence, rather than arguing that there is always something intrinsically authentic about volunteer tourism compared to everyday life, it would be more accurate to say that the popularity of volunteer tourism stems in large part from a search among individual volunteers for benefits and outcomes that touch upon existential themes.

Lastly, critics of volunteer tourism could argue that the existential authenticity offered by short-term volunteering activities is a shallow and transitory version of existentialism. It is shallow in the sense that volunteer tourism is more a transfer of everyday life to a foreign context than a true escape from the routines and rhythms of everyday life. Volunteers are therefore wedded to certain aspects of everyday life-including the feeling that they are 'living like a local' with daily routines and responsibilities-even as they remain removed from some of the less attractive dimensions of everyday life such as paying bills, finding a place to live, or being stuck in a job that brings little joy or novelty. Moreover, while some studies point to the long-term transformative impacts of volunteering on individuals (Bailey \& Russell, 2010; McGehee \& Santos, 2005), the vast majority of volunteers interviewed for this research question the degree to which their experiences will translate into momentous lifestyle changes back home. Thus, even though this paper argues that the pursuit of existential authenticity remains an important yet underexplored dimension of volunteer tourism, it would be a stretch to claim that short-term community service performed by volunteers in Thailand leads to the same existential outcomes as truly disruptive or traumatic experiences, many of which do indeed produce permanent alterations in values or life choices. Nevertheless, volunteer tourism should not be written off as 'existentialism lite' because the moments of existential authenticity made possible by volunteer tourism, even if ephemeral and not quite life-altering, are still valuable. Put simply, access to transitory, and perhaps even shallow, opportunities to reflect on one's life, to bond with others, and to enjoy a respite from the monotony of everyday life back home is certainly better than no such access at all.

\section{Acknowledgements}

The author would like to thank both the volunteers who gave up their time to participate in this research, and the directors, managers, and staff members of volunteer organizations whose generosity and cooperation greatly facilitated the completion of this study. 


\section{References}

Alexander, Z., \& Bakir, A. (2011). Understanding voluntourism: A Glaserian grounded theory study. In A. M. Benson (Ed.), Volunteer tourism: Theory framework to practical applications (pp. 9-29). London: Routledge.

Bailey, A., \& Russell, K. (2012). Volunteer tourism: Powerful programs or predisposed participants? Journal of Hospitality and Tourism Management, 19(1), $123-132$.

Bailey, A., \& Russell, K. (2010). Predictors of interpersonal growth in volunteer tourism: A latent curve approach. Leisure Sciences, 32(4), 352-368.

Barbieri, C., Santos, C. A., \& Katsube, Y. (2012). Volunteer tourism: On-the-ground observations from Rwanda. Tourism Management, 33(3), 509-516.

Belhassen, Y., Caton, K., \& Stewart, W. P. (2008). The search for authenticity in the pilgrim experience. Annals of Tourism Research, 35(3), 668-689.

Benson, A. M. (Ed.). (2011). Volunteer tourism: Theory framework to practical applications. London: Routledge.

Broad, S. (2003). Living the Thai life: A case study of volunteer tourism at the Gibbon Rehabilitation Project, Thailand. Tourism Recreation Research, 28(3), $63-72$.

Broad, S., \& Jenkins, J. (2008). Gibbons in their midst? Conservation volunteers' motivations at the Gibbon Rehabilitation Project, Phuket, Thailand. In K. Lyon \& S. Wearing (Eds.), Journeys of discovery in volunteer tourism: International case study perspectives (pp. 72-85). Cambridge, MA: CABI Publishing.

Brown, L. (2013). Tourism: A catalyst for existential authenticity. Annals of Tourism Research, 40, 176-190.

Brown, S. (2005). Travelling with a purpose: Understanding the motives and benefits of volunteer vacationers. Current Issues in Tourism, 8(6), 479-496.

Bruyere, B., \& Rappe, S. (2007). Identifying the motivations of environmental volunteers. Journal of Environmental Planning and Management, 50(4), 503-516.

Callanan, M., \& Thomas, S. (2005). Volunteer tourism: Deconstructing volunteer activities within a dynamic environment. In M. Novelli (Ed.), Niche tourism: Contemporary issues, trends and cases (pp. 183-201). Oxford: Butterworth-Heinemann.

Cary, S. H. (2004). The tourist moment. Annals of Tourism Research, 31(1), 61-77.

Chen, L. J., \& Chen, J. S. (2011). The motivations and expectations of international volunteer tourists: A case study of “Chinese Village Traditions". Tourism Management, 32(2), 435-442.

Coghlan, A. (2015). Prosocial behaviour in volunteer tourism. Annals of Tourism Research, 55, 46-60.

Coghlan, A., \& Gooch, M. (2011). Applying a transformative learning framework to volunteer tourism. Journal of Sustainable Tourism, 19(6), 713-728.

Coghlan, A., \& Fennell, D. (2009). Myth or substance: An examination of altruism as the basis of volunteer tourism. Annals of Leisure Research, 12(3-4), $377-402$.

Coghlan, A., \& Weiler, B. (2015). Examining transformative processes in volunteer tourism. Current Issues in Tourism, 1-16. 0.1080/13683500.2015.1102209.

Cohen, E. (1988). Authenticity and commoditization in tourism. Annals of Tourism Research, 15(3), 371-386.

Cohen, E., \& Cohen, S. A. (2012). Authentication: Hot and cool. Annals of Tourism Research, 39, 1295-1314.

Conran, M. (2011). They really love me! Intimacy in volunteer tourism. Annals of Tourism Research, 38(4), 1454-1473.

Coren, N., \& Gray, T. (2012). Commodification of volunteer tourism: A comparative study of volunteer tourists in Vietnam and in Thailand. International Journal of Tourism Research, 14(3), 222-234.

Crossley, E. (2012). Affect and moral transformations in young volunteer tourists. In D. Picard \& M. Robinson (Eds.), Emotion in motion: Tourism, affect and transformation (pp. 85-97). Farnham: Ashgate Publishing.

Daldeniz, B., \& Hampton, M. P. (2011). VOLUNtourists versus volunTOURISTS: A true dichotomy or merely a differing perception? In A. M. Benson (Ed.), Volunteer tourism: Theory framework to practical applications (pp. 30-41). London: Routledge.

Diprose, K. (2012). Critical distance: Doing development education through international volunteering. Area, 44(2), 186-192.

Galley, G., \& Clifton, J. (2004). The motivational and demographic characteristics of research ecotourists: Operation Wallacea volunteers in Southeast Sulawesi, Indonesia. Journal of Ecotourism, 3(1), 69-82.

Gnoth, J., \& Wang, N. (2015). Authentic knowledge and empathy in tourism. Annals of Tourism Research, 50, 159-172.

Goffman, E. (1959). The presentation of self in everyday life. Garden City, NY: Doubleday.

Golomb, J. (1995). In search of authenticity: From Kierkegaard to Camus. London: Routledge.

Graburn, N. (2001). Secular ritual: A general theory of tourism. In V. L. Smith \& M. Brent (Eds.), Hosts and guests revisited: Tourism issues of the 21st Century (pp. 42-50). New York: Cognizant Communication Corporation.

Grimm, K. E., \& Needham, M. D. (2012). Moving beyond the "I" in motivation: Attributes and perceptions of conservation volunteer tourists. Journal of Travel Research, 51(4), 488-501.

Halpenny, E. A., \& Caissie, L. T. (2003). Volunteering on nature conservation projects: Volunteer experiences, attitudes and values. Tourism Recreation Research, 28(3), 25-33.

Heidegger, M. (1962). Being and time. New York: Harper.

Hughes, G. (1995). Authenticity in tourism. Annals of Tourism Research, 22(4), 781-803.

Inwood, M. (1999). A Heidegger dictionary. Malden, Massachusetts: Blackwell.

Isaac, R. K. (2010). Alternative tourism: New forms of tourism in Bethlehem for the Palestinian tourism industry. Current Issues in Tourism, 13(1), 21-36.

Jones, A. (2011). Theorising international youth volunteering: Training for global (corporate) work? Transactions of the Institute of British Geographers, 36(4), $530-544$.

Keese, J. R. (2011). The geography of volunteer tourism: Place matters. Tourism Geographies, 13(2), 257-279.

Kim, H., \& Jamal, T. (2007). Touristic quest for existential authenticity. Annals of Tourism Research, 34(1), 181-201.

Kontogeorgopoulos, N. (2003). Keeping up with the Joneses: Tourists, travellers, and the quest for cultural authenticity in southern Thailand. Tourist Studies, 3(2), 171-203.

Kontogeorgopoulos, N. (2016). Forays into the backstage: Volunteer tourism and the pursuit of object authenticity. Journal of Tourism and Cultural Change, 121. http://dx.doi.org/10.1080/14766825.2016.1184673.

Lau, R. W. (2010). Revisiting authenticity: A social realist approach. Annals of Tourism Research, 37(2), 478-498.

Lee, Y. J., \& Woosnam, K. M. (2010). Voluntourist transformation and the theory of integrative cross-cultural adaptation. Annals of Tourism Research, 37(4), $1186-1189$.

Lepp, A. (2008). Discovering self and discovering others through the Taita Discovery Centre volunteer tourism programme, Kenya. In K. D. Lyons \& S. Wearing (Eds.), Journeys of discovery in volunteer tourism (pp. 86-100). Wallingford: CABI.

Lo, A. S., \& Lee, C. (2010). Motivations and perceived value of volunteer tourists from Hong Kong. Tourism Management, 32(2), 326-334.

Lyons, K. D., \& Wearing, S. (Eds.). (2008). Journeys of discovery in volunteer tourism. Wallingford: CABI.

MacCannell, D. (1973). Staged authenticity: Arrangements of social space in tourist settings. American Journal of Sociology, $589-603$.

MacCannell, D. (1976). The tourist: A new theory of the leisure class. Berkeley, CA: University of California Press.

Maslow, A. H. (1954). Motivation and personality. New York: Harper.

McDonald, M., \& Wilson, J. (2013). Volunteer tourism: An existential perspective. In S. L. Wearing \& N. McGehee (Eds.), International volunteer tourism: Integrating travellers and communities (pp. 105-115). Wallingford: CABI.

McGehee, N. (2002). Alternative tourism and social movements. Annals of Tourism Research, 29(1), 124-143.

McGehee, N. G., \& Santos, C. A. (2005). Social change, discourse and volunteer tourism. Annals of Tourism Research, 32(3), 760-779.

McIntosh, A. J., \& Zahra, A. (2007). A cultural encounter through volunteer tourism: Towards the ideals of sustainable tourism? Journal of Sustainable Tourism, 15(5), 541-556.

Mittelberg, D., \& Palgi, M. (2011). Self and society in voluntourism: A thirty-year retrospective analysis of post-trip self-development of volunteer tourists to the Israeli kibbutz. In A. M. Benson (Ed.), Volunteer tourism: Theory framework to practical applications (pp. 102-120). London: Routledge.

Mostafanezhad, M. (2014). Volunteer tourism: Popular humanitarianism in neoliberal times. Farnham, UK: Ashgate Publishing. 
Mostafanezhad, M. (2013a). 'Getting in Touch with your Inner Angelina': Celebrity humanitarianism and the cultural politics of gendered generosity in volunteer tourism. Third World Quarterly, 34(3), 485-499.

Mostafanezhad, M. (2013b). The politics of aesthetics in volunteer tourism. Annals of Tourism Research, 43, 150-169.

Mulder, N. (2000). Inside Thai society: Religion, everyday life, change. Chiang Mai, Thailand: Silkworm Books.

Mustonen, P. (2007). Volunteer tourism: Altruism or mere tourism? Anatolia, 18(1), 97-115.

Olsen, K. (2002). Authenticity as a concept in tourism research: The social organization of the experience of authenticity. Tourist Studies, 2(2), 159-182.

Pan, T. J. (2012). Motivations of volunteer overseas and what have we learned: The experience of Taiwanese students. Tourism Management, 33(6), $1493-1501$

Pearce, P. L., \& Coghlan, A. (2008). The dynamics behind volunteer tourism. In K. D. Lyons \& S. Wearing (Eds.), Journeys of discovery in volunteer tourism (pp. 130-143). Wallingford: CABI.

Pearce, D. G. (1992). Alternative tourism: Concepts, classifications, and questions. In V. L. Smith \& W. R. Eadington (Eds.), Tourism alternatives: Potentials and problems in the development of tourism (pp. 15-30). Philadelphia: University of Pennsylvania Press.

Pearce, P. L., \& Moscardo, G. M. (1986). The concept of authenticity in tourist experiences. Journal of Sociology, 22(1), 121-132.

Proyrungroj, R. (2014). Orphan volunteer tourism in Thailand: Volunteer tourists' motivations and on-site experiences. Journal of Hospitality and Tourism Research. 1096348014525639.

Reisinger, Y., \& Steiner, C. J. (2006). Reconceptualizing object authenticity. Annals of Tourism Research, 33(1), 65-86.

Rickly-Boyd, J. M. (2012). Lifestyle climbing: Toward existential authenticity. Journal of Sport and Tourism, 17(2), 85-104.

Schott, C. (2011). Young non-institutionalised volunteer tourists in Guatemala: Exploring youth and self-development. In A. M. Benson (Ed.), Volunteer tourism: Theory framework to practical applications (pp. 53-70). London: Routledge.

Selwyn, T. (1996). Introduction. In T. Selwyn (Ed.), The tourist image: Myths and myth-making in tourism (pp. 1-32). Chichester: John Wiley \& Sons.

Shepherd, R. J. (2015). Why Heidegger did not travel: Existential angst, authenticity, and tourist experiences. Annals of Tourism Research, 52, 60-71.

Sherraden, M. S., Lough, B., \& McBride, A. M. (2008). Effects of international volunteering and service. Individual and institutional predictors. Voluntas: International Journal of Voluntary and Nonprofit Organizations, 19(4), 395-421.

Sin, H. L. (2009). Volunteer tourism: 'Involve me and I will learn?'. Annals of Tourism Research, 36(3), 480-501.

Söderman, N., \& Snead, S. L. (2008). Opening the gap: The motivation of gap year travellers to volunteer in Latin America. In K. D. Lyons \& S. Wearing (Eds.), Journeys of Discovery in Volunteer Tourism (pp. 118-130). Wallingford, Oxfordshire: CAB International.

Steiner, C. J., \& Reisinger, Y. (2006). Understanding existential authenticity. Annals of Tourism Research, 33(2), 299-318.

Stoddart, H., \& Rogerson, C. M. (2004). Volunteer tourism: The case of habitat for humanity South Africa. GeoJournal, 60(3), 311-318.

Tiessen, R. (2012). Motivations for learn/volunteer abroad programs: Research with Canadian youth. Journal of Global Citizenship and Equity Education, 2(1), $2-12$.

Tomazos, K., \& Butler, R. (2009). Volunteer tourism: The new ecotourism? Anatolia. An International Journal of Tourism and Hospitality Research, $20,196-211$.

Tomazos, K., \& Butler, R. (2012). Volunteer tourists in the field: A question of balance? Tourism Management, 33(1), 177-187.

Tourism and Research Marketing (TRAM) (2008). Volunteer tourism: A global analysis. Arnhem, The Netherlands: ATLAS.

Turner, V. (1969). The ritual process: Structure and anti-structure. Chicago: Aldine Pub.

Turner, V. (1982). From ritual to theatre: The human seriousness of play. New York City: Performing Arts Journal Publications.

Uriely, N., Reichel, A., \& Ron, A. (2003). Volunteering in tourism: Additional thinking. Tourism Recreation Research, 28(3), 57-62.

Vrasti, W. (2012). Volunteer tourism in the global south: Giving back in neoliberal times. London: Routledge.

Wang, N. (1999). Rethinking authenticity in tourism experience. Annals of Tourism Research, 26(2), 349-370.

Wang, Y. (2007). Customized authenticity begins at home. Annals of Tourism Research, 34(3), 789-804.

Wearing, S. (2001). Volunteer tourism: Experiences that make a difference. Wallingford: CABI.

Wearing, S. (2003). Re-centering the self in volunteer tourism. In G. M. S. Dann (Ed.), The tourist as a metaphor of the social world (pp. 237-263). Wallingford: CABI.

Wearing, S. (2004). Examining best practice in volunteer tourism. In R. A. Stebbins \& R. T. Graham (Eds.), Volunteering as leisure/Leisure as volunteering (pp. 209-224). Wallingford, UK: CABI.

Wickens, E. (2011). Journeys of the self: Volunteer tourists in Nepal. In A. M. Benson (Ed.), Volunteer tourism: Theory framework to practical applications (pp. 42-52). London: Routledge.

Wrathall, M. A. (2013). Heidegger on human understanding. In M. A. Wrathall (Ed.), The Cambridge companion to Heidegger's 'Being and Time' (pp. 177-200). Cambridge: Cambridge University Press.

Wymer, W. W., Self, D. R., \& Findley, C. S. (2010). Sensation seekers as a target market for volunteer tourism. Services Marketing Quarterly, 31(3), 348-362.

Zahra, A. (2011). Volunteer tourism as a life-changing experience. In A. M. Benson (Ed.), Volunteer tourism: Theoretical frameworks and practical application (pp. 90-101). London: Routledge.

Zahra, A., \& McIntosh, A. J. (2007). Volunteer tourism: Evidence of cathartic tourist experiences. Tourism Recreation Research, $32(1), 115-119$.

Zavitz, K. J., \& Butz, D. (2011). Not that alternative: Short-term volunteer tourism at an organic farming project in Costa Rica. ACME: An International EJournal for Critical Geographies, 10(3), 412-441.

Nick Kontogeorgopoulos' research interests center on the relationship between tourism, environmental sustainability, and personal values. He has conducted research in Thailand on the impact of ecotourism on community development, the spatial and temporal relationship between ecotourism and mass tourism, the role of tourism in elephant conservation in northern Thailand, and the relationship between volunteer tourism and development. 